\title{
Dactylosporangium roseum sp. nov.
}

\author{
TAKASHI SHOMURA, * SHOICHI AMANO, HIROYOSHI TOHYAMA, JUNKO YOSHIDA, TATSUO ITO, \\ AND TARO NIIDA
}

Pharmaceutical Research Laboratories, Meiji Seika Kaisha, Ltd., 760, Morooka-cho, Kohoku-ku, Yokohama 222, Japan

A new species of Dactylosporangium is described, for which the name Dactylosporangium roseum is proposed. This organism is characterized by the rose color of its vegetative mycelium and its carbohydrate utilization pattern. The type strain of $D$. roseum is strain SF-2186 (=IFO 14352).

In the course of screening for new antibiotics, we isolated two actinomycetes (strain SF-2107 and strain SF-2186 ${ }^{\mathrm{T}}[\mathrm{T}=$ type strain]) which produce a new member of the orthosomycin group $(8,16)$ (antibiotic SF-2107 complex; Japan Kokai Patents 81-156297, 1981; 82-129692, 1982; 83-13392, 1983; assignee, Meiji Seika Kaisha, Ltd.).

These two strains are very similar in their characteristics and were found to belong to the genus Dactylosporangium Thiemann, Pagani and Beretta (13) on the basis of their characteristic morphology (i.e., formation of finger-shaped sporangia arising directly from the vegetative mycelium and new species of the genus Dactylosporangium. We designate strain SF-2186 as the type strain, because the characteristic rose color of its vegetative mycelium is more vivid than that of strain SF-2107.

In this report, we compare strain SF-2186 ${ }^{\mathrm{T}}$ with previously recognized species of Dactylosporangium.

\section{MATERIALS AND METHODS}

Bacterial strains. Strain SF-2186 ${ }^{\mathrm{T}}$ and strain SF-2107 (= ATCC 31744) were isolated in our laboratory from soil samples collected at Shizuoka, Japan, and Yokohama, Japan,

TABLE 1. Cultural characteristics of strains SF- $2186^{\mathrm{T}}$ and SF-2107“

\begin{tabular}{|c|c|c|c|c|c|c|}
\hline \multirow{2}{*}{ Medium } & \multicolumn{3}{|c|}{ Strain SF-2186 } & \multicolumn{3}{|c|}{ Strain SF-2107 } \\
\hline & Growth & Reverse color & Sporangia & Growth & Reverse color & Sporangia \\
\hline Sucrose-nitrate agar & $\begin{array}{l}\text { Very poor, } \\
\text { thin }\end{array}$ & Colorless & Abundant & $\begin{array}{l}\text { Very poor, } \\
\text { thin }\end{array}$ & Colorless & Abundant \\
\hline Glucose-asparagine agar & Very poor & Colorless & Abundant & Very poor & Colorless & Abundant \\
\hline $\begin{array}{l}\text { Glycerol-asparagine agar } \\
\text { (ISP medium 5) }\end{array}$ & Very poor & Colorless & Very abundant & Very poor & Colorless & Abundant \\
\hline $\begin{array}{l}\text { Inorganic salts-starch agar } \\
\quad \text { (ISP medium 4) }\end{array}$ & $\begin{array}{l}\text { Moderate to } \\
\text { good }\end{array}$ & Rose $(8 \mathrm{ic})$ & Very abundant & $\begin{array}{l}\text { Poor to } \\
\text { moderate }\end{array}$ & $\begin{array}{l}\text { Light rose beige } \\
(4 \mathrm{ec}) \\
\text { sometimes } \\
\text { rose }(8 \mathrm{ic})\end{array}$ & Abundant \\
\hline Calcium malate agar & Very poor & Colorless & Abundant & Very poor & Colorless & Abundant \\
\hline $\begin{array}{l}\text { Oatmeal agar (ISP } \\
\text { medium 3) }\end{array}$ & Moderate & Colorless & None & $\begin{array}{l}\text { Poor to } \\
\text { moderate }\end{array}$ & Colorless & None \\
\hline $\begin{array}{l}\text { Yeast extract-malt extract } \\
\text { agar (ISP medium 2) }\end{array}$ & $\begin{array}{l}\text { Moderate to } \\
\text { good }\end{array}$ & $\begin{array}{l}\text { Rose red } \\
\quad(8 \mathrm{pc})\end{array}$ & Poor & Moderate & $\begin{array}{c}\text { Amber }(3 \mathrm{lc}), \\
\text { sometimes } \\
\text { rose }(8 \mathrm{ic})\end{array}$ & $\begin{array}{l}\text { None or } \\
\text { poor }\end{array}$ \\
\hline $\begin{array}{l}\text { Tyrosine agar (ISP } \\
\text { medium 7) }\end{array}$ & $\begin{array}{l}\text { Poor to } \\
\text { moderate }\end{array}$ & $\begin{array}{l}\text { Melon yellow } \\
\text { (3ga) }\end{array}$ & Abundant & $\begin{array}{l}\text { Poor to } \\
\text { moderate }\end{array}$ & $\begin{array}{l}\text { Melon yellow } \\
\text { (3ga) }\end{array}$ & Abundant \\
\hline Nutrient agar & Poor & Colorless & Poor & Poor & Colorless & $\begin{array}{l}\text { None or } \\
\text { poor }\end{array}$ \\
\hline Bennett agar & Moderate & $\begin{array}{l}\text { Pastel orange } \\
\text { (4ic) to } \\
\text { amber }(3 \mathrm{lc})\end{array}$ & Poor & Moderate & $\begin{array}{l}\text { Melon yellow } \\
\text { (3ea) to } \\
\text { amber (3lc) }\end{array}$ & $\begin{array}{l}\text { None or } \\
\text { poor }\end{array}$ \\
\hline $\begin{array}{l}\text { Sucrose-yeast extract } \\
\text { agar }\end{array}$ & Good & $\begin{array}{l}\text { Rose }(8 \mathrm{ic}) \text { to } \\
\text { rose wine } \\
(8 \mathrm{le})\end{array}$ & None or poor & Good & $\begin{array}{l}\text { Rose }(8 \mathrm{ic}) \text { to } \\
\quad \text { rose red }(8 \mathrm{pc})\end{array}$ & Poor \\
\hline
\end{tabular}

${ }^{a}$ True aerial mycelia and diffusible pigments were not formed on all media. For an explanation of color designations, see reference 3.

three or four zoospores arranged in a single straight row inside a sporangium).

Based on a taxonomic comparison with known species, strain SF-2186 ${ }^{\mathrm{T}}$ and strain SF-2107 have been identified as a

\footnotetext{
* Corresponding author.
}

respectively. For comparative purposes, we studied the following strains: Dactylosporangium aurantiacum KCC A$0083^{\mathrm{T}}\left(=\mathrm{ATCC} 23491^{\mathrm{T}}\right)(14)$ and Dactylosporangium thailandense KCC A-0084 ${ }^{\mathrm{T}}$ (= ATCC $23490^{\mathrm{T}}(13,14)$, both of which were obtained from the KCC Culture Collection (Kaken Seiyaku Co. Ltd., Tokyo, Japan); Dactylosporangium matsuzakiense SF-2052 ${ }^{\mathrm{T}}$ (= ATCC $31570^{\mathrm{T}}$ ) (11) and Dactylospo- 

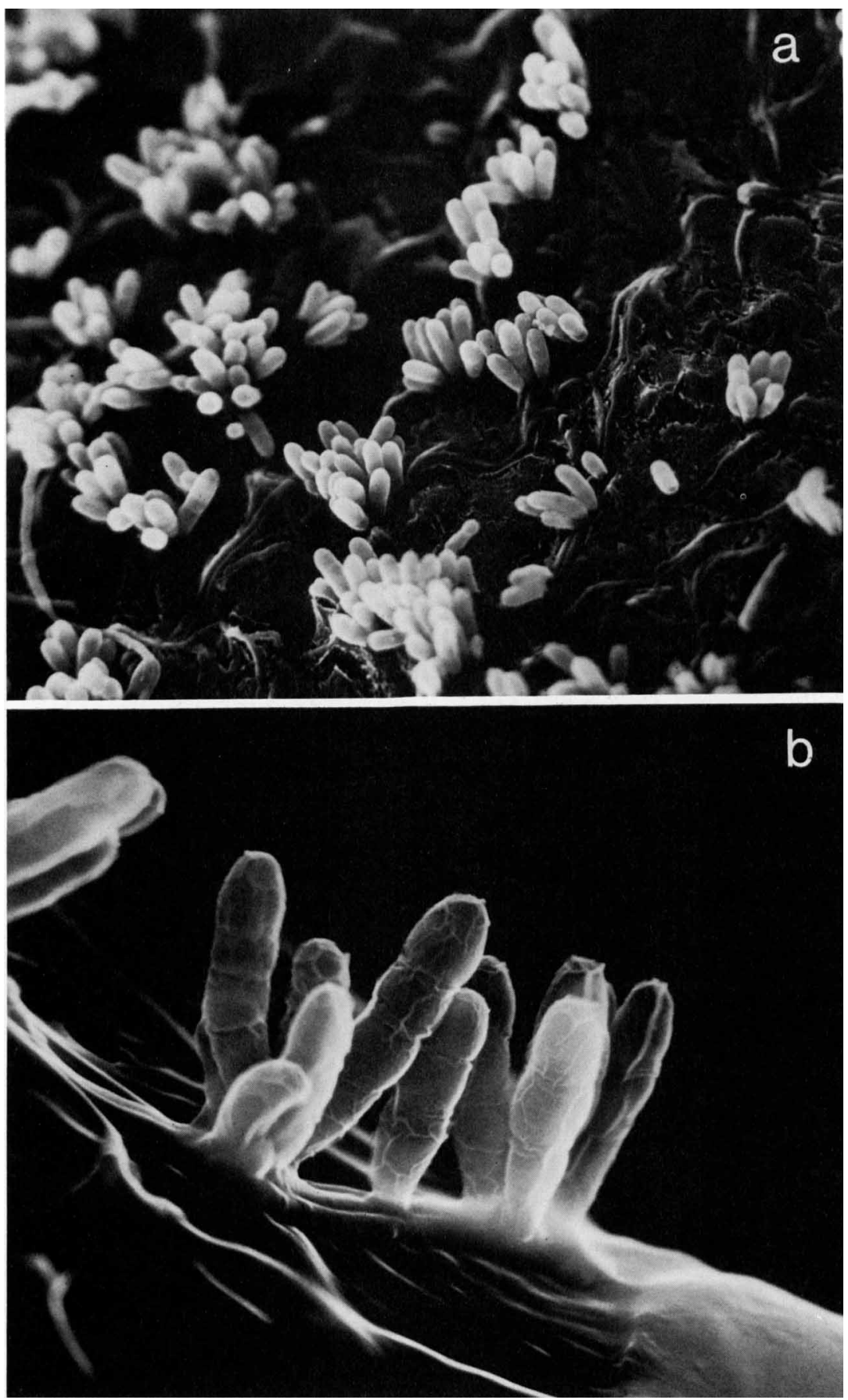

FIG. 1. Finger-shaped sporangia of strain SF-2186 ${ }^{\mathrm{T}}$ on glycerol-asparagine agar (ISP medium 5), as observed with a scanning electron microscope. The organism was incubated at $28^{\circ} \mathrm{C}$ for 14 days. (a) $\times 3,000$. (b) $\times 10,000$.

rangium vinaceum SF-2127 ${ }^{\mathrm{T}}$ (= IFO $14181^{\mathrm{T}}$ ) (12), which are strains from our laboratory.

Media. Washed cells were inoculated onto the following media: ISP media 2 to 7 (10); sucrose-nitrate agar; glucoseasparagine agar; nutrient agar; Bennett agar; and calcium malate agar of Waksman (15). Sucrose-yeast extract agar (sucrose, $10 \mathrm{~g}$; yeast extract [Difco Laboratories, Detroit, Mich.], $5 \mathrm{~g} ; \mathrm{CaCO}_{3}, 1 \mathrm{~g}$; agar [Difco], $15 \mathrm{~g}$; tap water added to $1,000 \mathrm{ml} ; \mathrm{pH}$ not adjusted) was used as an additional medium. Inoculated plates were incubated at $28^{\circ} \mathrm{C}$.
Morphological characterization. The morphologies of the sporangia and spores of the strains grown on glycerol-asparagine agar (ISP medium 5) and inorganic salts-starch agar (ISP medium 4) were studied by both light microscopy and electron microscopy. For scanning electron microscopy, an agar block containing numerous sporangia was fixed in $2.5 \%$ glutaraldehyde for $16 \mathrm{~h}$ and in osmium tetroxide fumes for 4 $\mathrm{h}$. The block was then gradually dehydrated by washing with increasing proportions of acetone and finally dried by the critical-point method (1). 


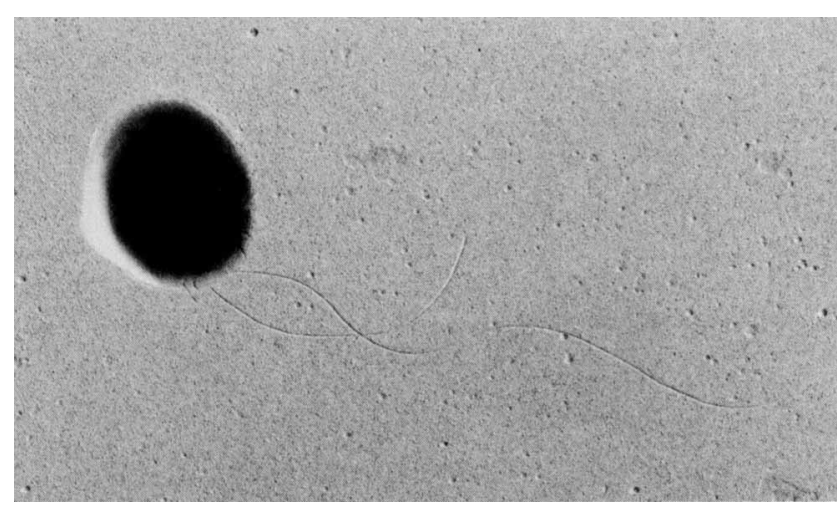

FIG. 2. Electron micrograph of a zoospore of strain SF-2186 ${ }^{\mathrm{T}}$. $\times 13,950$.

Each specimen was sputter-coated with gold-palladium and then examined with an electron microscope (model JEM100C-ASID; Japan Electron Optics Laboratory Co., Ltd.). For observation of zoospores, drops of a suspension containing zoospores were gently placed onto collodioncoated grids and air dried. The specimens were shadowed with platinum-palladium and examined with the electron microscope described above.

Cultural characterization. The cultural characteristics of the strains on various media were observed after 14 to 21 days of incubation at $28^{\circ} \mathrm{C}$. Color determinations were made by comparing the cultures with color chips from the Color Harmony Manual (3).

Physiological characterization. The media and procedures used for physiological characterization were the same as those outlined by Waksman (15) and Shirling and Gottlieb (10). The temperature range for growth was determined on ISP medium 4. $\mathrm{NaCl}$ tolerance was measured on Luedemann agar medium (6) containing different concentrations of $\mathrm{NaCl}$ $(0,1.5,3,4,5$, and $7 \%)$. Carbohydrate utilization was determined by the procedure of Luedemann and Brodsky (7).

Cell wall analysis. Cell walls were analyzed by the procedure of Becker et al. (2), and whole cells were analyzed by the method of Lechevalier (4).

\section{RESULTS AND DISCUSSION}

Morphological characteristics. The vegetative mycelium of strain SF-2186 ${ }^{\mathrm{T}}$ was fine, 0.5 to $0.7 \mu \mathrm{m}$ in diameter, long, irregularly branched, and twisted and penetrated into the agar. Fragmentation of hyphae usually did not occur either on agar or under submerged conditions. Aerial mycelia were not formed by agar cultures except for traces of rudimentary hyphae developing on oatmeal agar (ISP medium 3). Strain SF-2186 ${ }^{\mathrm{T}}$ produced finger-shaped sporangia. The sporangia emerged directly from the vegetative hyphae and were found singly or in clusters on the surface of the solid media. Sporangia were abundantly formed on all chemically defined media used, but were rare on organic media, such as yeast extract-malt extract agar (ISP medium 2), nutrient agar, and Bennett agar (Table 1).

With the scanning electron microscope, the sporangia appeared to be pod-shaped structures enveloping the spore chains (Fig. 1). The sporangia were 0.8 to 1.1 by 2.5 to 5.5 $\mu \mathrm{m}$ in size. Each sporangium usually contained three to four spores in a single straight row. The spores were elliptical and measured 0.8 to 1.1 by 0.6 to $1.5 \mu \mathrm{m}$. If the surface of a sporangium-containing culture was flooded with sterile water or soil extract solution, motile spores were observed after 30 to $60 \mathrm{~min}$ at room temperature. Electron microscopy of the spores revealed the presence of long polar flagella (Fig. 2). The formation of globose bodies, which have been described by Thiemann et al. (14) and Sharples and Williams (9), was not clearly observed in strain SF-2186 ${ }^{\mathrm{T}}$. The morphological characteristics of strain SF-2107 were identical to those of strain SF-2186 ${ }^{\mathrm{T}}$.

Cultural characteristics. Table 1 summarizes the degree of growth, formation of sporangia, and reverse color of the vegetative mycelia of strains $S F-2186^{\mathrm{T}}$ and $\mathrm{SF}-2107$ on various media. Neither strain formed true aerial mycelia or diffusible pigments on the agar media used. The most significant character of strain SF- $2186^{\mathrm{T}}$ was the rose color of its vegetative mycelium on selected media, such as inorganic salts-starch agar (ISP medium 4), yeast extract-malt extract agar, and sucrose-yeast extract agar. Strain SF-2107 showed the same rose color on sucrose-yeast extract agar, but rarely on inorganic salts-starch agar and yeast extract-malt extract agar. The rose color of the vegetative mycelium was not sensitive to $\mathrm{pH}$ changes, since no color change was observed when it was exposed to either $0.05 \mathrm{~N} \mathrm{NaOH}$ or $0.05 \mathrm{~N} \mathrm{HCl}$.

Physiological characteristics. The physiological characteristics of strain SF- $2186^{\mathrm{T}}$ are described below. Reduction of nitrate and liquefaction of gelatin are positive. Hydrolysis of starch, peptonization and coagulation of milk, and formation of melanoid pigment are all negative. Strain SF-2186 ${ }^{\mathrm{T}}$ grows within a temperature range of 20 to $42^{\circ} \mathrm{C}$, with an optimum

TABLE 2. Comparison of D. roseum SF-2186 ${ }^{\mathrm{T}}$ with the type strains of four other Dactylosporangium species

\begin{tabular}{|c|c|c|c|c|c|c|}
\hline \multirow[b]{2}{*}{ Strain } & \multicolumn{2}{|c|}{ Reverse color on: ${ }^{a}$} & \multirow[b]{2}{*}{ Diffusible pigment } & \multirow{2}{*}{$\begin{array}{l}\text { Hydrolysis } \\
\text { of starch }\end{array}$} & \multicolumn{2}{|c|}{ Utilization of: } \\
\hline & Oatmeal agar & $\begin{array}{l}\text { Sucrose-yeast } \\
\text { extract agar }\end{array}$ & & & D-Mannitol & L-Rhamnose \\
\hline $\begin{array}{l}\text { D. roseum SF- } \\
2186^{\mathrm{T}}\end{array}$ & Colorless & Rose $(8 \mathrm{ic})$ & None & $-b$ & - & - \\
\hline $\begin{array}{l}\text { D. aurantiacum } \\
\text { KCC A-0083 }\end{array}$ & $\begin{array}{l}\text { Light apricot } \\
\quad(4 \mathrm{ea})\end{array}$ & Shell (3ca) & None & + & + & + \\
\hline $\begin{array}{l}\text { D. thailandense } \\
\text { KCC A-0084 }\end{array}$ & $\begin{array}{l}\text { Russet orange } \\
(4 \mathrm{pc})\end{array}$ & $\begin{array}{l}\text { Orange rust } \\
\quad(4 \mathrm{pe})\end{array}$ & $\begin{array}{l}\text { Occassional, amber } \\
\text { or brown }\end{array}$ & + & + & + \\
\hline $\begin{array}{l}\text { D. matsuzakiense } \\
\text { SF-2052 }\end{array}$ & $\begin{array}{l}\text { Burnt orange } \\
\text { (5nc) }\end{array}$ & $\begin{array}{l}\text { Luggage-tan } \\
\text { (4ne) }\end{array}$ & $\begin{array}{l}\text { Occassional, light } \\
\text { brownish pink }\end{array}$ & + & + & + \\
\hline $\begin{array}{l}\text { D. vinaceum SF- } \\
2127^{\mathrm{T}}\end{array}$ & Wine $(7 \mathrm{pg})$ & $\begin{array}{l}\text { Ebony brown } \\
\text { (8pn) }\end{array}$ & Wine to deep red & + & + & + \\
\hline
\end{tabular}

\footnotetext{
${ }^{a}$ For an explanation of color designations, see reference 3 .
}

$b+$. Positive; - , negative. 
range of 28 to $37^{\circ} \mathrm{C}$. Strain SF-2186 ${ }^{\mathrm{T}}$ tolerates $1.5 \% \mathrm{NaCl}$, but no growth occurs on more than $3 \% \mathrm{NaCl}$.

When a Luedemann-Brodsky medium was used as the basal medium, this organism utilized D-glucose, D-fructose, and sucrose, but not D-mannitol, I-inositol, raffinose, or L-rhamnose. Utilization of D-xylose and L-arabinose is doubtful. The physiological characteristics of strain SF-2107 are identical to those of strain SF-2186 ${ }^{\mathrm{T}}$ described above.

Cell wall analysis. An analysis of cell wall hydrolysates of both strain SF-2186 ${ }^{\mathrm{T}}$ and strain SF-2107 by paper chromatography demonstrated the presence of 3-hydroxydiaminopimelic acid and a trace of meso-diaminopimelic acid. No LL isomer was detected. Sugar determination indicated that xylose and a trace of arabinose were present. Thus, both strain SF-2186 ${ }^{\mathrm{T}}$ and strain SF-2107 can be considered to have type II cell walls and whole cell sugar pattern D according to the classification scheme of Lechevalier and Lechevalier (5).

Identity of strain SF-2186 ${ }^{\mathrm{T}}$. The formation of finger-shaped sporangia containing motile spores, the absence of true aerial mycelia, and type II cell walls place strain SF-2186 ${ }^{\mathrm{T}}$ in the genus Dactylosporangium Thiemann et al. (14). Four species, D. aurantiacum $(14), D$. thailandense $(13,14), D$. matsuzakiense (11), and D. vinaceum (12), have been described previously as species of the genus Dactylosporangium. We compared strain $\mathrm{SF}-2186^{\mathrm{T}}$ directly with the type strains of these four previously described species. No outstanding differences in morphology were apparent among these four type strains and strain SF-2186 ${ }^{\mathrm{T}}$, regardless of whether sporangia or spores were compared. However, strain SF-2186 ${ }^{\mathrm{T}}$ differs clearly from the other four type strains in its cultural and physiological characteristics, as described below. $D$. vinaceum produces a wine to deep red diffusible pigment on almost all media used, whereas no obvious diffusible pigment was observed in strain SF-2186 on the same media. As shown in Table 2, the reverse colors of $D$. aurantiacum, D. thailandense, and D. matsuzakiense are apricot to orange on oatmeal agar, whereas the reverse of strain SF-2186 ${ }^{\mathrm{T}}$ is colorless. On the other hand, strain $\mathrm{SF}-2186^{\mathrm{T}}$ shows a distinctive rose reverse color on yeast extract-malt extract agar, on inorganic salts-starch agar, and especially on sucrose-yeast extract agar, whereas the other three species do not show such color on these media. In addition, strain SF-2186 ${ }^{\mathrm{T}}$ and the other four species differ in some physiological properties, such as starch hydrolysis and utilization of D-mannitol and L-rhamnose (Table 2).

In view of the characteristics described above, strain $\mathrm{SF}-2186^{\mathrm{T}}$ can be considered a new species of the genus Dactylosporangium, for which we propose the name Dactylosporangium roseum sp. nov. (ro'se.um. L. neut. adj. roseum rose colored, referring to the color of the vegetative mycelium). Strain SF-2186 is the type strain of D. roseum; a culture of this strain has been deposited in the Institute for Fermentation, Osaka, Japan, as strain IFO 14352.

\section{LITERATURE CITED}

1. Anderson, T. F. 1951. Techniques for the preservation of three-dimensional structure in preparing specimens for the electron microscope. Trans. N.Y. Acad. Sci. Ser. 2 13:130-134.

2. Becker, B., M. P. Lechevalier, and H. A. Lechevalier. 1965. Chemical composition of cell-wall preparations from strains of various form-genera of aerobic actinomycetes. Appl. Microbiol. 13:236-243.

3. Jacobson, E., W. C. Grauville, and C. E. Fogs. 1958. Color harmony manual, 4th ed. Container Corporation of America, Chicago.

4. Lechevalier, M. P. 1968. Identification of aerobic actinomycetes of clinical importance. J. Lab. Clin. Med. 71:934-944.

5. Lechevalier, M. P., and H. Lechevalier. 1970 . Chemical composition as a criterion in the classification of aerobic actinomycetes. Int. J. Syst. Bacteriol. 20:435-443.

6. Luedemann, G. M. 1971. Micromonospora purpureochromogenes (Waksman and Curtis 1916) comb. nov. (subjective synonym: Micromonospora fusca Jensen 1932). Int. J. Syst. Bacteriol. 21:240-247.

7. Luedemann, G. M., and B. C. Brodsky. 1964. Taxonomy of gentamicin-producing Micromonospora, p. 116-124. Antimicrob. Agents Chemother. 1963.

8. Ollis, W. D., C. Smith, and D. E. Wright. 1979. The orthosomycin family of antibiotics. I. The constitution of flambamycin. Tetrahedron 35:107-127.

9. Sharples, G. P., and S. T. Williams. 1974. Fine structure of the globose bodies of Dactylosporangium thailandense (Actinomycetales). J. Gen. Microbiol. 84:219-222.

10. Shirling, E. B., and D. Gottlieb. 1966. Methods for characterization of Streptomyces species. Int. J. Syst. Bacteriol. 16: 313-340.

11. Shomura, T., M. Kojima, J. Yoshida, M. Ito, S. Amano, K. Totsugawa, T. Niwa, S. Inouye, T. Ito, and T. Niida. 1980. Studies on a new aminoglycoside antibiotic, dactimicin. I. Producing organism and fermentation. J. Antibiot. 33:924-930.

12. Shomura, T., J. Yoshida, S. Miyadoh, T. Ito, and T. Niida. 1983. Dactylosporangium vinaceum sp. nov. Int. J. Syst. Bacteriol. 33:309-313.

13. Thiemann, J. E. 1970. Dactylosporangium thailandensis should be $D$. thailandense. Int. J. Syst. Bacteriol. 20:59.

14. Thiemann, J. E., H. Pagani, and G. Beretta. 1967. A new genus of the Actinoplanaceae: Dactylosporangium, gen. nov. Arch. Mikrobiol. 58:42-52.

15. Waksman, S. A. 1961. The actinomycetes, vol. 2. Classification, identification and description of genera and species. The Williams \& Wilkins Co., Baltimore.

16. Wright, D. E. 1979. The orthosomycins, a new family of antibiotics. Tetrahedron 35:1207-1237. 